\title{
Variability in Seed Yield of Multi-Cut Barseem Clover (Trifolium alexandrinum, L.) Gene Pool
}

\author{
M. Abd El-Sattar Ahmed ${ }^{1 *}$, Asmaa Mohamed Samir Rady ${ }^{2}$ and M. Fakhary Haeba ${ }^{3}$ \\ ${ }^{1}$ Crop Science Dept., Faculty of Agriculture (El-shatby), Alexandria University. (mohamed.A@alexu.edu.eg). \\ ${ }^{2}$ Crop Science Dept., Faculty of Agriculture (El-shatby), Alexandria University. \\ (asmaa.mohamed@alexu.edu.eg). \\ ${ }^{3}$ Post- graduate student, Crop Science Dept., Faculty of Agriculture (El-shatby), Alexandria University \\ ${ }^{*}$ Corresponding auther.
}

\begin{abstract}
The objective of the recent study was to detect variability in Egyptian multi-cut barseem gene pool via studying four different commercial populations regarding seed yield and seed yield components. These were; Khadarwi, Meskawi, Serow and Helaly. Means of total seed weight.plant ${ }^{-1}$ were approximately similar for Khadarawi (26.131g) and Meskawi (26.122) population. This was affected by similar figures for seed yield components. Serow population scored the least seed weight.plant ${ }^{-1}(21.981 \mathrm{~g})$ affected largely by the least number of seed.head ${ }^{-1}$ (37.79 seed.head $\left.{ }^{-1}\right)$. Meanwhile, Helaly population had the second least total seed weight.plant ${ }^{-1}(23.49 \mathrm{~g})$ affected also by low figure of number of seed.head ${ }^{-1}$. Major proportion of total variance $\left(\sigma^{2}\right.$ p)was contributed by the genotypic component $\left(\sigma^{2} g\right)$ in total seed weight. plant ${ }^{-1}$ and number of heads.plant ${ }^{-1}$ in all studied barseem populations. Whereas, the genotypic variance represented a very limited portion of phenotypic variance for other studied seed yield components in all studied populations. Heritability estimates in khadarawi and Meskawi populations postulated a strong genetic control on total seed weight .plant ${ }^{-1}$ and number of heads. plant $^{-1}(0.98$ and $0.97 \%)$. While, weak estimates were recorded for number of seeds.head ${ }^{-1}$, seed weight.head ${ }^{-1}$ and 1000 seed weight $(0.23,0.13$ and $0.04 \%$, respectively). Estimates of expected gain from selection the top $10 \%$ of half-sib families of khadarawi population might result in 59.85\% increase in total seed weight, which amount to15.64 g.plant ${ }^{1}$.Concerning Helaly population selecting the top $10 \%$ of half-sib families might result in total seed weight.plant ${ }^{-1}$ and number heads.plant ${ }^{-1}$ increase of 72.43 and $67.09 \%$ which might amount to 17.01 g.plant ${ }^{-1}$ and 105.8 heads.plant ${ }^{-1}$.
\end{abstract}

keywords: barseem clover, half-sib families, seed yield, PCV, GCV, heritability, genetic gain.

\section{INTRODUCTION}

Barseem clover "Trifolium alexandrinum,L." is the second principle winter crop in Egypt. The area devoted for barseem cultivation approach 3 million Faddans. Produced barseem forage is consumed as soiling during winter and spring or hay and silage during summer and fall.

Seed yield is a second product of barseem cultivations. The monetary value of produced seed yield per unit area is approaching similar value to seasonal forage yield. In the meantime, the yield of seed is an exportable commodity to mediterranean basin countries that share with Egypt, barseem's cultivation.

Breeding for improved seed yield of barseem clover gained special interest in the last years. The success of programs depends upon the excisting variability and the nature of genetic control on seed yield and yield component characters. Little available review regarding variability in seed yield and seed yield components of barseem clover illustrates the need for further studies. Variability in multi-cut type of barseem clover has been studied for forage yield and plant characters (Radwan and Abou-El-Fittoh 1970; Ali, 1971; El-Nahrawy, 1980; Bakheit, 1985; Mahdy,1988; Rady, 2008; Badwy, 2013; Abd El-Naby et al, 2014 and Ahmed et $a l, 2015)$. Large genetic variability has been found for seed yield and seed yield components. Recorded estimates for seed yield heritability reached 0.63 (Bakheit, 1989), 0.97(Ahmed, 1992), 0.52 (Martiniello and Lannucci, 1998) and 0.595 (Rajab, 2010). Farid et al ,(1972) found that seed setting percentage was responsible for most of seed yield variations rather than 1000 seed weight .Phenotypic variation in seed yield amounted to $27 \%$ of obtained mean yield (Ahmed,1992),19.0\% (Martiniello and Lannucci, 1998), 27.3\% (Ahmed, 2000) and 12.7\% (Rady,2008).

The objective of the recent study was to detect variability in Egyptian multi-cut barseem gene pool via studying four different commercial populations regarding seed yield and seed yield components.

\section{MATERIALS AND METHODS}

The recent study was carried-out at the experimental farm of Alexandria University located in Abbis $10 \mathrm{~km}$ south of Alexandria city.Multi-cut gene pool of barseem was represented by four distinguished populations. These were; Khadarwi, Meskawi, Serow and Helaly.All four populations were registered and released by the Forage Crops Research Department (FCRD), Field Crop Research Institute (FCRI), Agricultural Research Center (A.R.C), Egypt.

In (2014-2015) winter season, seeds of the four populations were sown at the rate of $31.4 \mathrm{~kg} \cdot \mathrm{ha}^{-1}$ in 
hand drilled rows $4.0 \mathrm{~m}$ long and $20 \mathrm{~cm}$ apart $(2.5 \mathrm{~g}$ per plot). Populations were timely isolated by allowing a successive flowering started with Meskawi population, then Serow, then Helaly and finally Khadarawi populations. Serow Population flowered after three cutting since sown in midNovember. Whereas, Meskawi that sown in early October flowered after four cuttings. Helaly population that was sown in early November produced four cuttings and flowered before the last (Table 1).

At flowering, 300 plants with overall visual characters in each population were selected. Seeds from each plant were harvested separately to represent a half-sib family. One hundred half-sib families from each population with adequate seed were saved.

In (2015-2016) winter season, half-sib families of each population were evaluated in a separate experiment. Families of each population were divided to five sets each of twenty families. Each set was evaluated in a randomized complete block experiment with three replicates. Each plot represented by a single row 1.5 long and 0.2 on apart. Seeding rate was 31.4 kg.ha ${ }^{-1}$ (1.03g.plot ${ }^{-1}$ ). Families rows were successively alternating. Sowing dates, cutting table and probable flowering dates were similar to what mentioned during the first year of the study (Table 1). Ten random plants from each plot were used to measure number of head.plant ${ }^{-1}$, number of seeds.head- ${ }^{1}$, seed weight.head ${ }^{-1}, 1000$ seed weight and total seed weight.plant ${ }^{-1}$.

Data were statistically analyzed for each population as outlined by Steel and Torrie (1980). Estimates of genetic $\left(\sigma^{2} \mathrm{~g}\right)$, phenotypic $\left(\sigma^{2} \mathrm{p}\right)$, environmental $\left(\sigma^{2} \mathrm{e}\right)$ variances and heritability on means of plant basis as $\mathrm{h}^{2}=\left[\sigma^{2} \mathrm{~g} / \sigma^{2} \mathrm{p}\right]$ was calculated as given by Hallauer and Miranda (1981). Phenotypic (P.C.V.) and genotypic (G.C.V.) coefficients of variability were calculated according to Burton and De Vance (1953).

\section{RESULTS AND DISCUSSION}

Analysis of variance indicated significant differences in total seed weight.plant ${ }^{-1}$ and other seed yield component characters (i.e; number of head.plant $^{-1}$, number of seeds.head ${ }^{-1}$, seed weight.head ${ }^{-1}$ and 1000 seed weight) among halfsib families of Khadarawi and Helaly population. In both Meskawi and Serow population, the differences among the studied half-sib families in
1000 seed weight had not reached the level of significance (Table 2). Means of total seed weight.plant ${ }^{-1}$ were approximately similar for Khadarawi (26.131g) and Meskawi (26.122) population. This was affected by similar figures for seed yield components. Serow population scored the least seed weight.plant ${ }^{-1}$ (21.981g) affected largely by the least number of seed.head ${ }^{-1}$ (37.79 seed.plant ${ }^{-1}$ ). Meanwhile, Helaly population had the second least total seed weight.plant ${ }^{-1}(23.49 \mathrm{~g})$ affected also by low value of number of seed.head ${ }^{-}$ 1. The magnitude of ranges for total seed weight.plant $^{-1}$ among populations were very wide reached maximum value in Helaly population $(51.61-4.87=46.74 \mathrm{~g})$ followed by the corresponding value in Serow population (51.80$7.33=43.47 \mathrm{~g})$. The narrowest range in total seed weight.plant $^{-1}$ was recorded in Khadarawi population $(53.86-9.10=44.76 \mathrm{~g})$ followed by Meskawi population $(49.65-9.25=40.40 \mathrm{~g})$. the widest range in number of heads.plant ${ }^{-1}$ were recorded for Khadarawi and Helaly population (512-10 and 417-62, respectively). Whereas, Meskawi and Serow populations exhibited very narrow range in this character (55-43 and 58-49, respectively).

Number of seeds.head ${ }^{-1}$ ranged similary among half- sib families of the four populations (96-15, 90-15, 81-15 and 89-15 seeds.head ${ }^{-1}$ for Khadarwi, Meskawi, Serow and Helaly populations, respectively). The same was true for seed weight.head ${ }^{-1}$ and 1000 seed weight. Commonly, it seems that the most differentiating seed yield characters among half-sib families of populations representing the multi-cut barseem gene pool might be number of heads.plant ${ }^{-1}$ and seed weight.plant ${ }^{-1}$.

Phenotypic and genotypic variances, phenotypic and genotypic coefficients of variability, heritability, genetic advance from selection as units and genetic advance as percentage of the character mean are presented in (Table 3). Major proportion of total variance $\left(\sigma^{2} p\right)$ was contributed by the genotypic component $\left(\sigma^{2} \mathrm{~g}\right)$ in total seed weight.plant ${ }^{-1}$ and number of heads.plant ${ }^{-1}$ in all studied barseem populations. Whereas, the genotypic variance represented a very limited portion of phenotypic variance for other studied seed yield components in all studied populations.

Table1: Sowing dates, Cutting table and Flowering dates of barseem populations.

\begin{tabular}{|c|c|c|c|c|c|c|c|c|}
\hline \multirow[b]{2}{*}{ Population } & \multirow[b]{2}{*}{ Sowing date } & \multicolumn{6}{|c|}{ Cuttings } & \multirow{2}{*}{ flowering date } \\
\hline & & $1^{\text {st }}$ & $2^{\text {nd }}$ & $3^{\mathrm{rd}}$ & $4^{\text {th }}$ & $5^{\text {th }}$ & $6^{\text {th }}$ & \\
\hline Meskawi & $1^{\text {st }}$ Oct. & $1 / 12$ & $11 / 1$ & $11 / 2$ & $11 / 3$ & & & $1 / 4$ \\
\hline Serow & $15^{\text {th }}$ Nov. & $15 / 1$ & $25 / 2$ & $25 / 3$ & & & & $20 / 4$ \\
\hline Helaly & $1^{\text {st }}$ Nov. & $10 / 1$ & $20 / 2$ & $20 / 3$ & $20 / 4$ & & & $20 / 5$ \\
\hline Khadarawi & $15^{\text {th }}$ Oct. & $15 / 12$ & $25 / 1$ & $25 / 2$ & $25 / 3$ & $25 / 4$ & $25 / 5$ & $15 / 6$ \\
\hline
\end{tabular}


Table 2: Mean squares from ANOVA, ranges and means of half-sibs Seed yield characters of 100 halfsib families from each of Khadarawi, Meskawi, Serow and Helaly populations of barseem clover.

\begin{tabular}{|c|c|c|c|c|}
\hline \multirow[t]{2}{*}{ Character } & \multirow[t]{2}{*}{ Range } & \multirow[t]{2}{*}{ Mean } & \multicolumn{2}{|c|}{ Mean square } \\
\hline & & & Half-sib & Error \\
\hline \multicolumn{5}{|c|}{ Khadarawi } \\
\hline Number of heads.plant ${ }^{-1}$ & $(10-512)$ & 170.054 & $18918.48^{* * *}$ & 122.082 \\
\hline Number of seeds.head $^{-1}$ & $(15-96)$ & 46.301 & $1393.38^{*}$ & 1151.386 \\
\hline Seed weight.head $^{-1}$ & $(0.05-0.35)$ & 0.168 & $0.006^{*-1}$ & 0.002 \\
\hline 1000 seed weight & $(3.3-3.7)$ & 3.408 & $0.009^{*}$ & 0.007 \\
\hline Total seed weight.plant $^{-1}$ & $(9.1-53.86)$ & 26.131 & $359.810^{* *}$ & 1.816 \\
\hline \multicolumn{5}{|c|}{ Meskawi } \\
\hline Number of heads.plant $^{-1}$ & $(55-43)$ & 164.288 & 15196.078 ** & 97.546 \\
\hline Number of seeds.head $^{-1}$ & $(15-90)$ & 46.650 & $317.758^{* *}$ & 148.504 \\
\hline Seed weight.head $^{-1}$ & $(0.06-0.29)$ & 0.178 & $0.005^{* *}$ & 0.002 \\
\hline 1000 seed weight & $(3.3-3.9)$ & 3.462 & $0.022^{n . s}$ & 0.026 \\
\hline Total seed weight.plant $^{-1}$ & $(9.25-49.65)$ & 26.122 & 315.459 & 1.327 \\
\hline \multicolumn{5}{|c|}{ Serow } \\
\hline Number of heads.plant $^{-1}$ & $(58-49)$ & 165.47 & $21881.436^{* *}$ & 311.940 \\
\hline Number of seeds.head $^{-1}$ & $(15-81)$ & 37.788 & 204.148 & 136.443 \\
\hline Seed weight.head $^{-1}$ & $(0.06-0.28)$ & 0.144 & $0.003^{*}$ & 0.002 \\
\hline 1000 seed weight & $(3.3-3.9)$ & 3.435 & $0.012^{\text {n.s }}$ & 0.015 \\
\hline Total seed weight.plant $^{-1}$ & $(7.33-51.8)$ & 21.981 & $330.587^{* *}$ & 28.248 \\
\hline \multicolumn{5}{|c|}{ Helaly } \\
\hline Number of heads.plant $^{-1}$ & $(62-417)$ & 157.723 & $16471.823^{* *}$ & 100.537 \\
\hline Number of seeds.head $^{-1}$ & $(15-89)$ & 41.593 & $444.604^{* *}$ & 169.748 \\
\hline Seed weight.head $^{-1}$ & $(0.05-0.34)$ & 0.159 & $0.007^{*-1}$ & 0.002 \\
\hline 1000 seed weight & $(3.3-3.9)$ & 3.450 & $0.021^{*}$ & 0.019 \\
\hline Total seed weight.plant $^{-1}$ & $(4.87-51.61)$ & 23.486 & $432.906^{* *}$ & 2.767 \\
\hline
\end{tabular}

Table 3: Phenotypic variance $\left(\sigma^{2} p\right)$, genotypic variance $\left(\sigma_{g}^{2}\right)$, phenotypi coefficient of Variation (P.C.V.), genotypic coefficient of variation (G.C.V.), heritability $\left(h^{2}\right)$, genetic advance (G.A) and genetic advance as \% of amean (G.A\%) for seed yield characters of Khadarawi, Meskawi, Serow and Helaly populations of barseem clover.

\begin{tabular}{|c|c|c|c|c|c|c|c|c|c|}
\hline \multirow{3}{*}{ Characters } & \multirow{3}{*}{$\sigma^{2} p$} & \multirow{3}{*}{$\sigma^{2} \mathbf{g}$} & \multicolumn{7}{|c|}{ Estimate } \\
\hline & & & \multirow[t]{2}{*}{ P.C.V } & \multirow[t]{2}{*}{ G.C.V } & \multirow[t]{2}{*}{$\mathbf{h}^{2}$} & \multicolumn{2}{|c|}{ G.A } & \multicolumn{2}{|c|}{ G.A\% } \\
\hline & & & & & & $10 \%$ & $20 \%$ & $10 \%$ & $20 \%$ \\
\hline \multicolumn{10}{|c|}{ Khadarawi } \\
\hline Number of heads.plant $^{-1}$ & 4821.1 & 4699.1 & 40.83 & 40.31 & 0.97 & 112.5 & 94.29 & 66.14 & 55.45 \\
\hline Number of seeds.head $^{-1}$ & 1211.8 & 60.49 & 75.19 & 16.79 & 0.05 & 2.85 & 2.39 & 6.16 & 5.16 \\
\hline Seed weight.head $^{-1}$ & 0.003 & 0.001 & 32.61 & 18.82 & 0.67 & 0.087 & 0.073 & 51.79 & 43.45 \\
\hline 1000 seed weight & 0.007 & 0.0005 & 2.54 & 2.07 & 0.07 & 0.009 & 0.008 & 0.26 & 0.23 \\
\hline Total seed weight.plant $^{-1}$ & 91.31 & 89.49 & 36.57 & 36.20 & 0.98 & 15.64 & 13.11 & 59.85 & 50.17 \\
\hline \multicolumn{10}{|c|}{ Meskawi } \\
\hline Number of heads.plant $^{-1}$ & 3872.1 & 3774.6 & 0.38 & 0.38 & 0.97 & 100.8 & 84.50 & 61.36 & 51.43 \\
\hline Number of seeds.head $^{-1}$ & 190.81 & 42.314 & 0.29 & 0.14 & 0.23 & 5.31 & 4.45 & 11.38 & 9.54 \\
\hline Seed weight.head $^{-1}$ & 0.0058 & 0.0007 & 0.43 & 0.15 & 0.13 & 0.017 & 0.014 & 9.55 & 7.87 \\
\hline 1000 seed weight & 0.025 & 0.01 & 0.05 & 0.009 & 0.04 & 0.011 & 0.008 & 0.32 & 0.25 \\
\hline Total seed weight.plant $^{-1}$ & 79.86 & 78.533 & 0.34 & 0.34 & 0.98 & 14.63 & 12.26 & 56.01 & 46.93 \\
\hline \multicolumn{10}{|c|}{ Serow } \\
\hline Number of heads.plant $^{-1}$ & 5704.3 & 5392.4 & 0.46 & 0.44 & 0.95 & 119.8 & 100.45 & 75.41 & 60.71 \\
\hline Number of seeds.head $^{-1}$ & 153.4 & 16.93 & 0.33 & 0.11 & 0.11 & 2.27 & 1.91 & 6.01 & 5.05 \\
\hline Seed weight.head $^{-1}$ & 0.005 & 0.0003 & 0.47 & 0.11 & 0.06 & 0.007 & 0.006 & 4.86 & 4.14 \\
\hline 1000 seed weight & 0.014 & 0.0008 & 0.034 & 0.008 & 0.05 & 0.009 & 0.0084 & 0.29 & 0.24 \\
\hline Total seed weight.plant $^{-1}$ & 103.8 & 75.59 & 0.46 & 0.39 & 0.73 & 12.42 & 10.41 & 56.50 & 47.36 \\
\hline \multicolumn{10}{|c|}{ Helaly } \\
\hline Number of heads.plant $^{-1}$ & 4179.9 & 4079.3 & 0.41 & 0.40 & 0.98 & 105.8 & 88.70 & 67.09 & 56.24 \\
\hline Number of seeds.head $^{-1}$ & 238.5 & 68.71 & 0.37 & 0.19 & 0.29 & 7.48 & 6.27 & 17.98 & 15.07 \\
\hline Seed weight.head $^{-1}$ & 0.005 & 0.003 & 0.028 & 0.31 & 0.56 & 0.06 & 0.05 & 37.7 & 31.45 \\
\hline 1000 seed weight & 0.019 & 0.0005 & 0.040 & 0.006 & 0.026 & 0.006 & 0.005 & 0.17 & 0.14 \\
\hline Total seed weight.plant $^{-1}$ & 110.3 & 107.5 & 0.45 & 0.44 & 0.97 & 17.01 & 14.26 & 72.43 & 60.72 \\
\hline
\end{tabular}


Phenotypic and genotypic coefficient of variability in khadarawi population reached $40 \%$ of over all mean of half-sib families in number of heads.plant ${ }^{-}$ $1,36 \%$ in total seed weight.plant ${ }^{-1}$. Whereas, genotypic coefficient of variability for number of seed.head ${ }^{-1}$ represented $16.79 \%$ of families mean regarded by $75.19 \%$ phenotypic coefficient of variation. Variation at genotypic level in 1000 seed weight reached $2.07 \%$ of families mean regarded by $2.54 \%$ at phenotypic level. In other populations, variability at phenotypic or genotypic levels in all seed yield characters, showed negligible value as percentage of each population's families mean.Farid et al (1972) detected large figures for coefficient of variability for seed yield. He added that, seed setting percentage was responsible for most of seed yield variations rather than 1000 seed weight. Ahmed (1992) reached that, phenotypic differences among barseem entries in seed yield amounted to 30.31 and $27 \%$ of obtained mean yield of the first, second seasons and combined yield. Ahmed (2000) revealed that, phenotypic coefficient of variation for seed yield was 27.32\%.EL-Nahrawy (2007), reached that P.C.V. for seed yield over seasons was high. Rady (2008) showed a (P.C.V.) for seed yield as $12.7 \%$. Rajab (2010) recorded the highest (P.C.V.) values for seed yield followed by number of seeds.inflorescence ${ }^{-1}$. Rady (2008), reached the lowest significant values of seeds per inflorescence with Saidi and Meskawi populations, which were insignificantly different(37.13 and 41.6 seeds.head ${ }^{-}$ ${ }^{1}$,respectively). While, Khadarwi I population exhibited the highest number of seeds.head ${ }^{-1}(52.33$ seeds.head ${ }^{-1}$ ). Variations in seeds setting as (P.C.V) reached 13 to $86 \%$ while (G.C.V) reached $7 \%$.

Heritability estimates in khadarawi population postulated a strong genetic control on total seed weight . plant $^{-1}$ and number of heads.plant ${ }^{-1}(0.98$ and $0.97 \%$ ). Also, seed weight.head ${ }^{-1}$ gave a strong estimate of heritability (0.67\%). In the meantime, genetic control on number of seeds.head ${ }^{-1}$ and 1000 seed weight is relatively weak $(0.05$ and $0.07 \%)$. In Meskawi population, strong estimates of heritability were recorded for total seed weight.plant ${ }^{-1}$ and number of heads.plant ${ }^{-1}(0.98$ and $0.97 \%$ ). While, weak estimates were recorded for number of seeds.head ${ }^{-1}$ seed weight.head ${ }^{-1}$ and 1000 seed weight $(0.23,0.13$ and $0.04 \%$, respectively). As for Serow population, strong estimates of heritability were recorded for number of heads.plant ${ }^{-1}$ and total seed weight.plant ${ }^{-1}(0.95$ and $0.73 \%$, respectively). Helaly population, had a strong estimates of heritability for number of heads.plant ${ }^{-1}$, total seed weight. plant ${ }^{-1}$ and seed weight.head $^{-1}(0.98,97$ and $0.56 \%$, respectively). On the other hand, estimates for other seed yield component were relatively weak. Malengier and Baer (2007) estimated heritability of seed yield in red clover. Estimates were high amounted to 0.82 in the first season. Bakheit (1989) estimated broadsense heritability for seed yield of barseem clover from variance components as $63.03 \%$. Ahmed (1992) reached an estimate of 0.97 for seed yield of barseem. Rajab (2010) estimated heritability in broad-sense for seed yield as $0.96 \%$.

Estimates of expected gain from selection the top $10 \%$ of half-sib families of khadarawi population might result in $59.85 \%$ increase in total seed weight, which amount to 15.64 g.plant ${ }^{-1}$. Also, it might result in $66.14 \%$ increase in number of heads.plant ${ }^{-1}$ which amount to 94.29 head.plant $^{-1}$. In addition, an increase in seed weight.head ${ }^{-1}$ might $^{-1}$ reach $51.79 \%$ which amount to 0.087 g. head ${ }^{-1}$. Regarding Meskawi population selecting the top $10 \%$ of studied half-sib families might result in an increases of 56.61 and $61.36 \%$ in total seed weight.plant ${ }^{-1}$ and number of heads.plant ${ }^{-1}$, which might amount to 14.63 g.plant and 100.8 head.plant ${ }^{-1}$. Improvements in other studied seed yield components were negligible. As for Serow population, the highest figures of response to selecting the top $10 \%$ half-sib families were recorded for number of heads.plant ${ }^{-1}$ and total seed weight.plant ${ }^{-1}(72.41$ and $56.50 \%)$ which amount to 119.8 heads.plant ${ }^{-1}$ and 12.42 g.plant ${ }^{-1}$. Concerning Helaly,strong improvement associated with selecting the top $10 \%$ of half-sib families were detected with total seed weight.plant ${ }^{-1}$ and number heads.plant $^{-1}(72.43$ and $67.09 \%)$ which might amount to 17.01 g.plant and 105.8 heads.plant ${ }^{-1}$. A moderate genetic advance was recorded for seed weight.head ${ }^{-1} \quad(37.74 \%$ which amount to 0.05 g. head $^{-1}$.

Genetic gain from selecting the top $20 \%$ of half-sib families in all studied populations was parallel to what noticed with $10 \%$ selection intensity with the advantage of keeping larger variability that enable successive cycles of selection.Abou- ELShawareb (1971) obtained a gain from selection reached 19.9 to $29.0 \%$ in seed yield of Meskawi barseem clover. Bakheit (1989) recorded a realized gain in seed yield from selection amounted to $17.47 \%$. Ahmed (2000), obtained a realized gain in seed yield of barseem of $8.55 \%$ from index selection. Ahmed (2006) obtained a gain from selection in seed yield lowest when half- sib families were evaluated. Bakheit et al. (2007) recorded a realized gain in seed yield of barseem ranged between 13.59 and $18.45 \%$.

Commonly, the genetic coefficient of variability is a measure of relative genetic variation. Breeders can't rely on such measure alone, because it is a function of both genetic variation and population mean. The expected genetic advance is more appropriate to compare the gain from selection than heritability as the former combines heritability, phenotypic variation and 
selection differential. High genetic advance values for seed weight. plant ${ }^{-1}$ and number of heads. plant ${ }^{-}$

1 indicated that these characters were governed largely through the additive affect of genes and the improvement in these characters might be achieved through phenotypic selection (Johnson et al, 1955).

\section{REFERENCES}

Abou El-Shawareb, O. (1971). Comparative efficiency of mass and recurrent selection breeding methods in the improvement of Egyptian "Barseem" (Trifolium alexanrinum, L.) Ph.D., faculty of Agric, Cairo Univ., Egypt.

Abd El-Naby, Zeinab. M, Wafaa,W. M. Shafie and M.A.El- Nahrawy(2014). Genetic analysis and meternal effects in barseem clover. Life. Sci. J.11 (55): 407-418.

Ahmed, M. AbdEl-Sattar, M. N. Barakat, andA. M. S. Rady(2015). Genotypic variation in Egyptian gene pool of barseem clover (Trifolium alexandrinum,L.). Egypt.J. Plant. Breed. 19(3):307-326.

Ali, F.M. (1971). The effect of mass selection on forage yield and related traits in barseem clover (Trifolium alexandrinum, L.). M.Sc. Thesis, Cairo Univ., Giza, Egypt.

Ahmed, M. Abd El-Sattar (1992). Improvement of barseem clover (Trifolium alexandrinum, L.) by different methods of selection. Ph.D. Dissertation, Faculty of Agriculture, Alexandria University, Egypt.

Ahmed, M.Abd EL-Sattar (2000) .Comparison of single trait with multiple trait selection in Barseem clover (Trifolium alexandrinum ,L.) .J. Agric. Sci. Mansoura Univ, 25: 4601- 4613.

Ahmed, M. Abd El-Sattar (2006). Variability, correlations and path-coefficient analysis in two populations of multi-cut Barseem clover. Alex. J. Agric. Res., 51 (2): 63-72.

Badawy,A.S.M.(2013).Recurrent selection for seed yield in Helaly barseem clover. Ph.D. Thesis.Fac.Agric.,Alex.univ.,Egypt.

Bakheit, B. R. (1985). Effect of mass and family selection on productivity of Egyptian clover (Trifolium alexandrinum, L.). Assuit. J.Agric.Sci. 16: 35-46.

Bakheit, B.R. (1989). Selection for seed yield production of Egyptian clover (Trifolium alexandrinum, L.) c.v. Fahl. Plant Breed. 103: 278-285.

Bakheit, B.R. M.A.Ali and A.M. Abo EL- Wafa (2007).The efficiency of selection for seed yield in the fahl variety of Egyption (barseem) clover, (Trifolium alexandrinum, L.). J Agric. Sci. Mansoura Univ. 32 (1): 1-19.

Burton, G.W. and De Vance, E.H. (1953). Estimating heritability in Tall Fescue (Festuca orundinacea) from replicated clonal material.Agron. Jour. 45: 478-481.
El-Nahrawy, M.A. (1980). A study of variation in productivity of farmers seed lots of Meskawi barseem (Trifolium alexandrinum, L.). M. Sc. Thesis, in Agronomy, Fac. Agric. Cairo Univ. Egypt.

El-Nahrawy, S.M.A. (2007). Estimates of phenotypic and genotypic variances for forage and seed yields in some cultivars of barseem clover (Trifolium alexandrinum,L.) under two location. M.Sc. Thesis. in Agronomy, Fac. Agric. Kafr El-Sheikh Univ., Egypt.

Farid, N.I.; L.F. Tanash and A.M. Moustafa (1972). Comparative study of some imported varieties of "Trifolium alexandrinum, L.", compared with the local variety Giza-1 and the effect of number of cuttings on their seed yield. Agric. Res .Rev. 50: 89-106.

Johnson, H. W.; H. F. Robinson and Comstock, R. E. (1955). Estimates of genetic and environmental variability in soybean. Agron. J., 47: 274-318.

Hallauer, A.R. and J.B. Miranda (1981). Quantitatitative Genetics in Maize Breeding. Iowa State Univ. Press Ames.USA.

Mahdy, E.E. (1988). Selection under two plant densities for forage yield of Meskawi clover (Trifolium alexandrinum,L.). Assiut. J. Agric. Sci. 19: 243-252.

Malengier, M., Baer, J. (2007). Heritability of seed yielding capacity in tetraploid red clover (Trifolium pratense,L.). $27^{\text {th }}$ EUCARPIA Symposium on Improvement of Fodder Crops and Amenity Grasses Kopenhagen.Denmark, P21 (Abstract).

Martiniello, P. and A. Lannucci (1998). Genetic variability in herbage and seed yield in selected half-sib families of barseem clover (Trifolium alexandrinum,L.). Plant Breeding 117: 559562.

Radwan, M.S.and H.A. Abou-El-Fittoh (1970). Evaluation of berseem clover varieties in field versus nursery plots. Contemporary Agriculture 6: 515-519.

Rady, A.M.S. (2008). Estimation of morphological and genetic variations in barseem clover gene pool. M.Sc. Thesis in Crop Sci, Fac. Agric.Alex. Univ. Egypt.

Rajab, M.N. (2010). Studies on breeding of Egyptian clover (Trifolium alexandrinum,L.). Ph.D. Dissertation, Fac. Agric. Minia Univ., Egypt.

Steel, R.G.D. and J.H Torrie. (1980). Principles and Procedures of Statistics: A BiometricaL' Approach. McGraw-Hill Book Company, New York, 633pp. 


\title{
تصنيفات محصول البذرة في الوعاء الجيني للبرسيم المصري متعدد الحشات
}

\section{"Trifolium alexandrinum, L."}

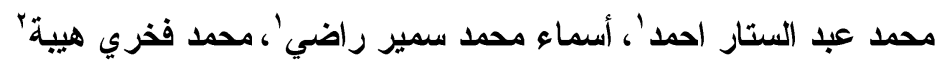

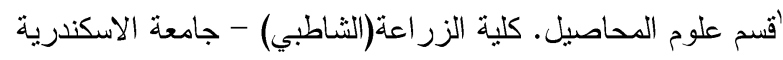

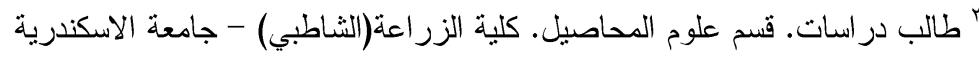

\section{الملخص العربي}

الهدف من الدر اسة الحالية هو تقدير الاختلافات في الوعاء الجيني للبرسيم المصري من خلال دراســـة اربعــة

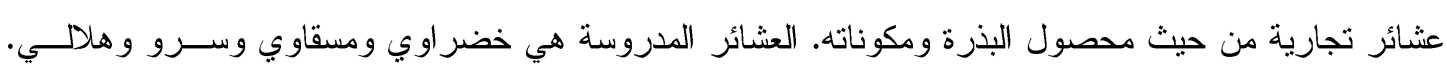

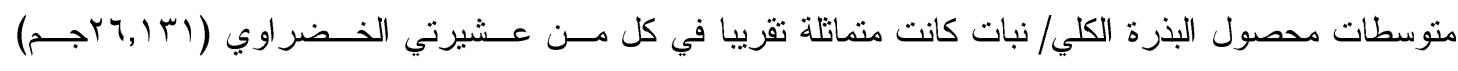

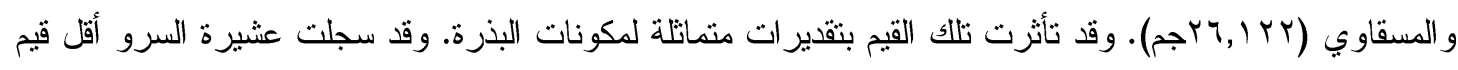

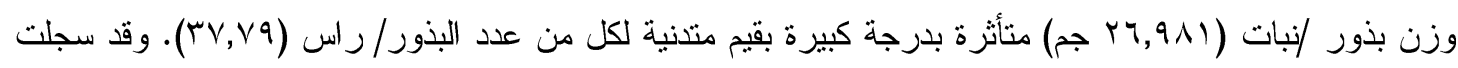

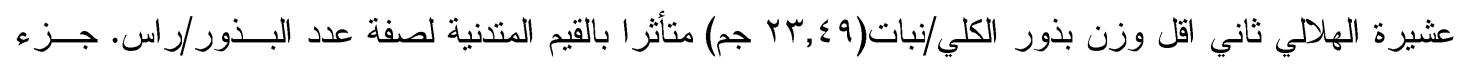

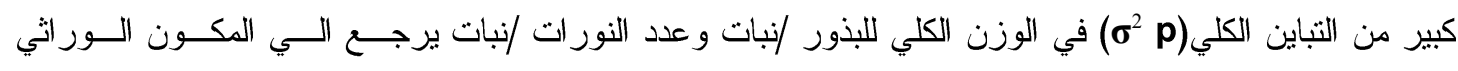

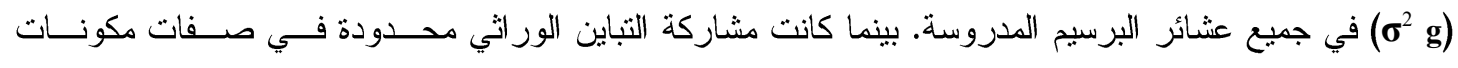

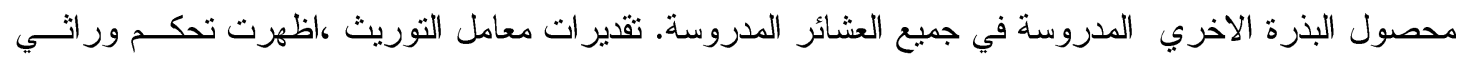

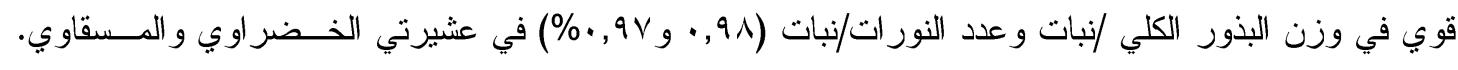

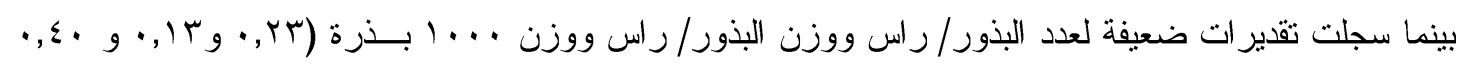

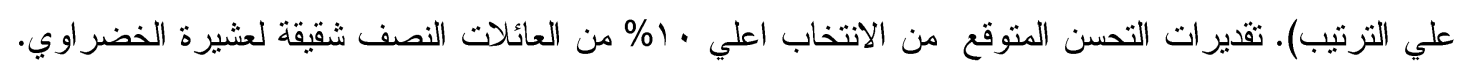

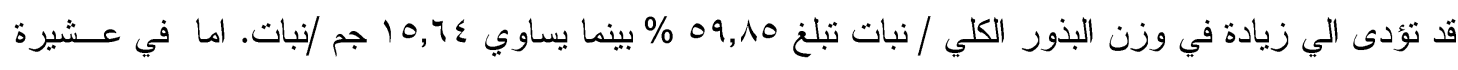

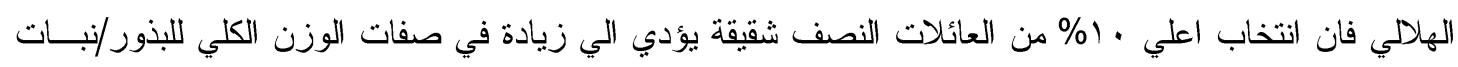

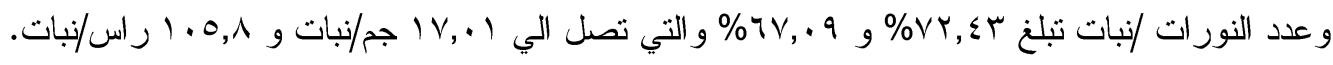

